\title{
THE TREATMENT OF THE ARCHITECTURAL UNIT ABOVE OPENINGS OF THE MAMLUK AND OTTOMAN FACADES IN CAIRO
}

Heba Mahmoud Saad Abdel Naby

\author{
Former Fulbright Scholar at Mary Baldwin College, VA, \\ USA \\ Currently Associate Professor of Islamic Art and \\ Architecture Alexandria University, Egypt \\ e-mail: h.saad@gmail.com
}

Received: May $6^{\text {th }}$ 2014; Accepted: June $17^{\text {th }}$ 2014; Available Online: December $15^{\text {th }} 2014$

\begin{abstract}
The facades of the Mamluk buildings have a common characteristic feature which is the use of lintels, nafis and relieving arches above doors and windows. The three elements together formed a unit with an important architectural function on the façades. This unit was also treated as a focal point of the façade. Therefore, it was richly decorated with floral and geometric decorations and was usually made of colored marble, joggles voussoirs or carved stones. As a result, that unit attracted the attention of pedestrians and added to the beauty of the façade.

During the Ottoman period the same unit was used on facades, however, due to financial and political reasons, the materials used differed and the decorations became modest. Nonetheless, the decoration of the lintel, nafis and relieving arch managed to mark the Ottoman facades with a different identity.
\end{abstract}

Keywords: Façade, the Mamluk buildings, decoration, identity

\begin{abstract}
Abstrak
Fasad bangunan pada dinasti Mamluk memiliki karakteristik yang sama pada bukaan seperti pada pintu, jendela dengan penggunaan relief lengkung. Ketiga elemen membentuk satu kesatuan yang penting secara fungsi dan estetika terutama pada fasade. Elemen tersebut menjadi focal point pada fasad. Fasad memiliki estetika yang kaya akan ornamen dengan bentukan sulur-sulur bunga dan bentukan geometris yang bermaterial marmer atau batu. Sehingga dengan ornamen tersebut menjadi daya tarik tersendiri bagi pengguna terutama pejalan kaki dalam melihat fasad.

Selama periode Ottoman, ornamen yang dipakai pada fasad mempunyai karakter yang sama namun berbeda pada penggunaan material karena pengaruh dari politik pada masa itu, sehingga ornamen yang terbentuk berkesan lebih sederhana. Bentukan tersebut yang menjadi identitas pada bangunan di periode Ottoman.
\end{abstract}

Kata Kunci: Tampak bangunan, Bangunan dinasti Mamluk, ornamen, identitas

\section{Introduction}

The Fatimid capital, al-Qahira, was inhabited by the Ayyubids, the Mamluks and then the Ottomans; therefore, its streets were crowded with buildings dating to the different eras. The Mamluks were keen to locate their buildings on important streets so most of their buildings have at least one street facade. That led to a noticeable care for the layout and decoration of facades. The common feature that marked the Mamluk facades was the tradition of paneling the façade with recesses pierced with windows. The recesses were pierced with superimposed windows; rectangular at the lower level and arched at the upper level. The entrance of the building was another recess that was usually deeper than the rest, but not necessarily in the centre of the façade, and included the portal. Such openings on the facades allowed visual communication with the street and created unprecedented visual effect that was highlighted with the decoration above the openings. The present study focuses on the treatment of the architectural unit that was located above façade openings; doors and windows, which included lintel, nafis and relieving arch. This unit marked the facades of both the Mamluk and Ottoman buildings.

The study aims to explain the treatment of this architectural unit during the Mamluk and Ottoman periods. Thus, it intends to explain its construction, decoration, development and importance. To achieve that, the research focused on the buildings of four main streets of al-Qahira. The chosen streets were of high importance and they were crowded with buildings that varied in their function, size, importance, position of their patrons and date. The first street is al-Mu'iz Street that was the main street of the capital running from Bab Zuwayla in the south to Bab al-Nasr in the north. An extension to that street was created when the city expanded outside the Fatimid walls during the Mamluk period. That is the second street which is running from the south of Bab Zuwayla till it intersects with Muhammad Ali Street (including al-Khayamia, al-Megharbelin and alSurugia). The third street is Suq al-Silah Street which 
starts from al-Rifaci mosque, running north and turning left till it intersects with al-Khayamia Street, south of Bab Zuwayla. The fourth street is al-Saliba Street which starts from Salah al-Din square and ends with al-Sayeda Zainab square (Map 1). The facades of the various buildings overlooking those four streets were examined, focusing on the treatment of the part above doors and windows. The total number of examined facades is 66 including 4 Fatimid buildings, 2 Ayyubid, 15 Bahari Mamluk, 19 Circassian Mamluk and 23 Ottoman.

The study is divided into two parts; the first is descriptive; covering the construction and decoration of the studied unit (lintel, nafis and relieving arch) and providing various examples of each type of decoration from the studied buildings. The second is analytical; focusing on the development of decoration, their variations through ages, their importance, and their effect on viewer. This part also discussed the interaction between buildings and the mutual influence between them.

\section{Part 1: The Descriptive study}

The unit above openings: lintel, nafis and relieving arch

The most important part of any opening in masonry is its upper part. The two basic solutions to construct this part are either an arch formed by brick or wedge-shaped stones, or a lintel[1]. The lintel was commonly used to surmount doors during the Mamluk period. It was made of a slab of marble, stone or wood and in that case the door was described in endowment deeds as "bab muraba" or "a square door", together with a description of its material[2],[3]. The same applies to rectangular windows. Lintels in Cairo were sometimes mixed constructions, in that only the visible part was made of joggled stone or a thin stone revetment blending in with the dressed masonry of the façade. The remaining thickness of the wall was taken up by a series of timber beams[1].

Lintels of doors and windows of Mamluk and Ottoman buildings in Cairo were usually surmounted with relieving arches. Each is a composite structure formed of a series of wedge-shaped blocks (voussoirs) set side by side and held together in compression[4],[5]. The relieving arch could also be known as segmental arch; which is a shallow arch with a curve less than a semicircle. Such an arch was constructed above the lintel in order to carry a much greater load than a lintel can carry; because downward pressure forces the voussoirs to gather instead of being apart and carry more weight[6],[7]. Both the lintel and the relieving arch were used as load-bearing elements; moreover, they were also used as decorative elements of the facades. The area between the lintel and the relieving arch is known as Nafis or Tympanum[8].

The three parts together were commonly used as a unit that surmounted the doors and windows of Mamluk buildings and the same tradition also continued during the Ottoman period.

\section{Construction and Decoration}

Although the use of the lintel, nafis and relieving arch was witnessed in Islamic architecture in Egypt as early as the Fatimid period, their use was exceptionally unique during the Mamluk and Ottoman periods. The Mamluks in particular paid special care for their execution and displayed a wide variety in their decoration and material.

The examination of the facades of Mamluk and Ottoman buildings revealed that the architect had two choices for constructing lintels and relieving arches. The first was to use only one type of stone (marble, limestone, sandstone.) and the second was to use an ordinary type of stone and cover it with a thin layer of joggled stone, usually marble, to be visible to people and reveal a rich look of the façade.

In many cases the architect preferred to use one slab of stone for the lintel, which rested on the two side shoulders of the door opening and provided a considerable strength to that opening. The slab was made of white marble such as in the entrances of al-Ashraf Barsbay madrasa (829 A.H./ 1425 A.D.) (Figure 1), Abd al-Rahman Katkhuda zawia (1142 A.H./ 1729A.D.) (Figure 8) and his sabil in al-Muciz Street (1157 A.H./ 1744 A.D.) and the entrance of Ali al-Mutahhar mosque (1157 A.H./ 1744 A.D.). In other cases the lintel was made of a slab of granite such as in the entrances of Shaykhu khanqah and madrasa (750-756 A.H./ 1349-1355 AD.), Ulgay alYusufi madrasa (774 A.H./ 1373 A.D.) and al-Ghawri madrasa (909-10 A.H./ 1504-5 A.D.) Neither marble nor granite was used for lintels of windows.

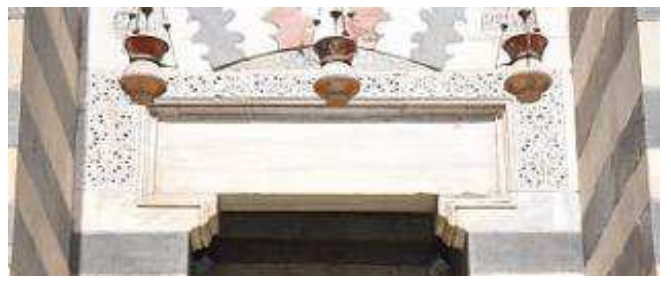

Figure 1: Lintel of marble- Entrance of al-Ashraf Barsbay madrasa

A large number of lintels were also constructed by using joggled voussoirs in order to provide more support to the lintel and also have a decorative shape. A keystone with a special shape was used and the rest of voussoirs were arranged on its sides to be interlacing with each others. The Mamluk architect created a wide range of joggled voussoirs that were used for constructing lintels and relieving arches[9][10]. The voussoirs were made of dressed stone and their size varied according to the size of the masonry of the façade and the weight they should carry[11]. The joggled voussoirs were generally cut of two different colours of limestone used alternately or cut of different colours of marble that formed a thin layer covering and decorating the original stone lintel or relieving arch[12]. They varied between simple designs and complex designs. a- Joggled voussoirs with simple designs: 
The simple designs included stepped voussoirs that were used for the lintel of entrances such as that of Sarghatmish madrasa (757 A.H./ 1356 A.D) and the side entrance of al-Mu'ayyad mosque (818-23 A.H./ 1415-20 A.D.). Stepped voussoirs were also used for the construction of many lintels of façade windows such as in al-Maridani mosque (739-40 A.H./ 1339-40 A.D.), the sabil window of Ulgay al-Yusufi madrasa, Inal al-Yusufi madrasa (794-5 A.H./ 139293 A.D.), Qanibay mosque (816 A.H./ 1413 A.D.), Sulaymania takiyya (950 A.H./ 1543 A.D.) (Figure 2) and al-Fakahani mosque (1148 A.H./ 1735 A.D.). The stepped joggled voussoirs were also witnessed in the relieving arch of the sabil window of Farag ibn Barquq zawia (811 A.H./ 1408 A.D.).

The sloping voussoirs were more suitable for relieving arches as seen in the relieving arch of the façade windows of al-Nasir Muhammad madrasa (695-703 A.H./ 1295-1304 A.D), Sangar al-Gawli madrasa (703 A.H./1303-4 A.D.), Sarghatmish madrasa, Inal al-Yusufi madrasa, Qanibay mosque, Sulaymania takiyya (Figure 2) and Abd Allah Katkhuda Azaban sabil ( 1132 A.H./ 1719 A.D.) (Figure 3).

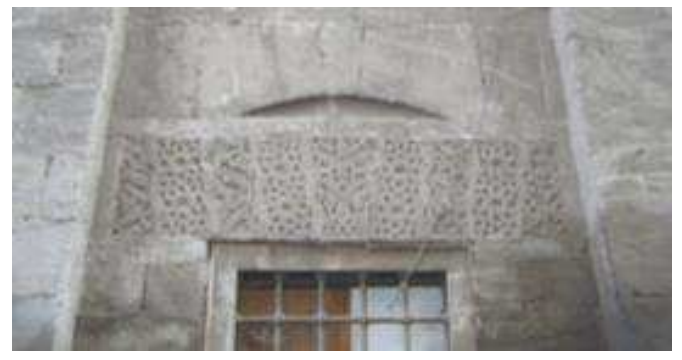

Figure 2: Stepped voussoirs of lintel and sloping voussoirs of relieving arch-Sulaymania takiyya side facade

The wavy voussoirs were also among the simple types of voussoirs used for both lintels and relieving arches. This type was created by cutting the sides of voussoirs in concave and convex shapes. Examples of such form were seen in the lintels of the entrance of Qalawun complex (683-84 A.H./ 1284-85 A.D.), the entrance of Sangar al-Gawli madrasa, the entrance of Barquq madrasa (786-88 A.H./ 1384-86 A.D.), the façade windows of al-Ghawri madrasa and Abd Allah Katkhuda Azaban sabil (Figure 3). They were also seen in many relieving arches such as the relieving arch of the entrance of al-Ashraf Barsbay madrasa (Figure 1), the relieving arches of the façade windows of Taghri Bardi madrasa (844 A.H./ 1440 A.D.), the façade window of Mustafa Sinan sabil (1040 A.H./ 1630 A.D.) and the entrance of Abd alRahman Katkhuda sabil (Figure 15).

It is worth mentioning that the above mentioned types of voussoirs were usually cut of limestone only, either of one colour or two colours used alternately. Only the wavy type of voussoirs (with concave and convex sides) was executed on both coloured stone and coloured marble.

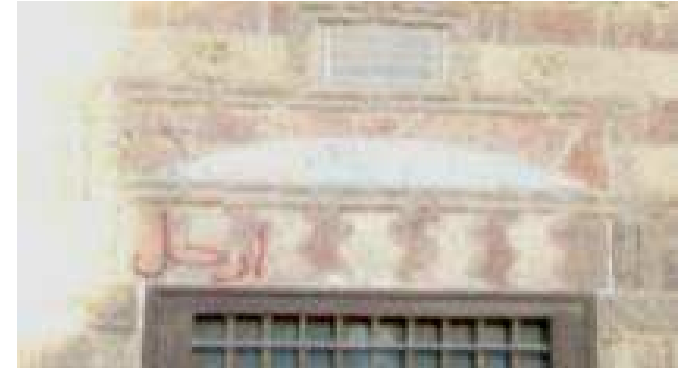

Figure 3: Wavy voussoirs of lintel and slopping voussoirs of relieving arch - Abd Allah Katkhuda Azaban sabil

a- Joggled voussoirs with complex and elaborate designs

The complex joggled voussoirs could be divided into two main groups of designs; the floral designs and the geometric designs. The trefoil flower was the main motif of floral designs that was widely used for voussoirs with a variety of shapes and degrees of complication. The first type of voussoirs presented the trefoil flower cut on the sides of the voussoirs in a horizontal position. It seems that this type of voussoirs was generally used for relieving arches. In some cases only one trefoil flower flanked with two leaves were cut on voussoirs such as in the relieving arch of the entrances of al-Maridani mosque, Ulgay al-Yusufi madrasa, Barquq madrasa, al-Mu'ayyad mosque, Jani Bek mosque (830 A.H./ 1426-27 A.D.), Taghri Bardi madrasa, , and al-Ghawri khanqah (90910 A.H./ 1504-5 A.D.). They are also seen in the relieving arches of the façade windows of al-Ghawri sabil and Khusraw sabil (942 A.H./ 1535 A.D.) (Figure 4). In other cases, three trefoil flowers were cut on the sides of the voussoirs such as in the relieving arch of a window of Qaytbay sabil (884 A.H./ 1479 A.D) (Figure 6) and the lintel of a window of Yusuf Bek sabil (1044 A.H./ 1634 A.D.).

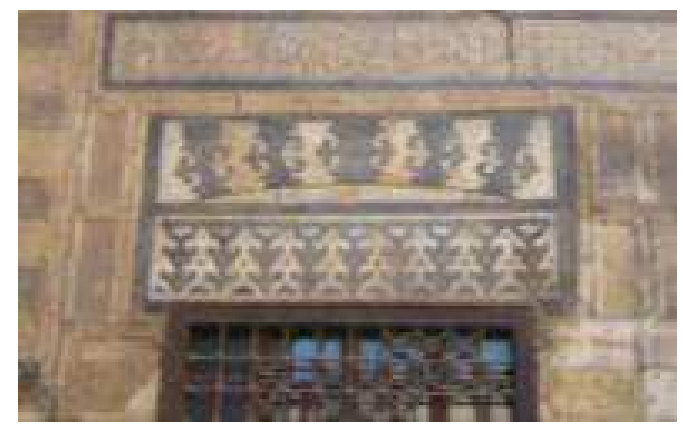

Figure 4: Lintel with trefoil complex flower and relieving arch with trefoil flower- Khusraw sabil

Mamluk craftsmen modified the trefoil flower into a new style presenting each flower framed with two facing ogee curves to form a heart-shaped frame and to separate the flower from the reversed adjacent one[13]. White and black marble were usually used for that design to emphasize the alternating forms of the trefoil flower. This design was seen in the lintel of the entrance of al-Nasir Muhammad madrasa in addition to the façade 
windows of al-Kurdi mosque (797 A.H./ 1395 A.D.), al-Ashraf Barsbay madrasa (Figure 5), Jani Bek mosque and Taghri Bardi madrasa. A unique example of trefoil flower framed with a heart-shaped frame is seen in the relieving arch of the entrance of Farag ibn Barquq zawia. The trefoils are cut on a small scale and set in horizontal position on the sides of the voussoirs, maintaining the alternating colours together with accurate and skillful execution.

Another development occurred when craftsmen added more than one tier of leaves to the trefoil motif to become a complex motif rather than a simple one. This pattern was made of white marble on a black background of marble too. The void created between each two patterns of the same colour was at the same time another pattern in reverse and of the opposite colour. This style of joggled voussoirs was used in the lintels of entrances such as that of Ahmad al-Mihmandar mosque (725 A.H./ 1324-25 A.D.), Farag Ibn Barquq zawia and Taghri Bardi madrasa. It was also used in lintels of façade windows of Barquq madrasa, al-Mu'ayyad mosque, Jani Bek mosque, Taghri Bardi madrasa, alGhawri sabil and Khusraw sabil (Figure 4).

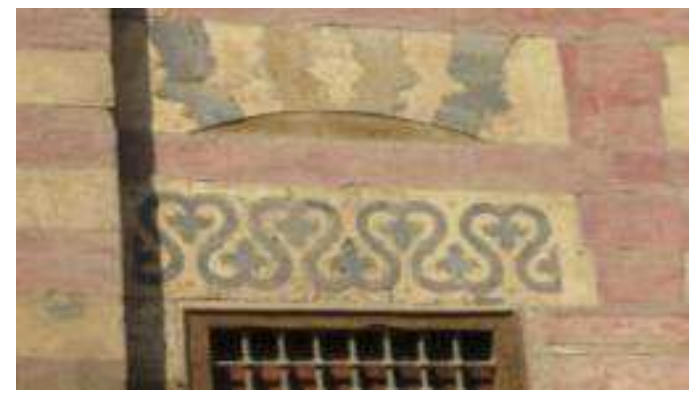

Figure 5: Lintel with trefoil flowers with heart-shaped frames- Facade window of al-Ashraf Barsbay madrasa

The arabesque is another elaborate design that was rarely used for joggled voussoirs due to its complex form. The arabesque is a special ornament that included curved scrolls together with leaves, palmettes and rosettes which are varying in size and degree of stylization. The elements of the design are intimately connected with each others with rhythmical alternation of movement always rendered with harmonious effect[14],[15],[16],[17]. The use of arabesque was witnessed in the lintels of windows of Qaytbay sabil which were made of coloured marble.

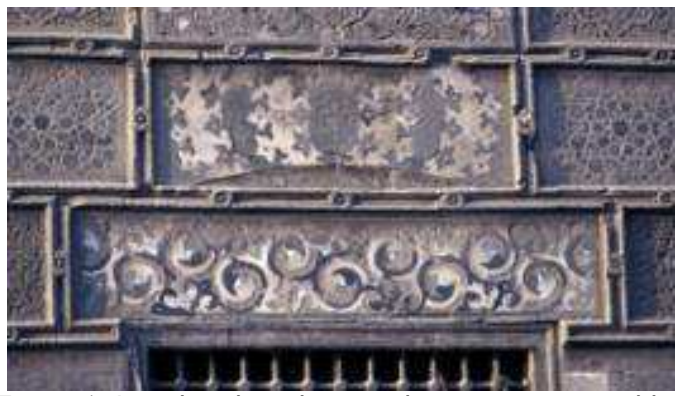

Figure 6: Lintel with arabesque decorations on marbleFacade window of Qaytbay sabil
Like the arabesque, geometric designs were also used to decorate joggled voussoirs as a thin layer of coloured marble. The star pattern, which parts were filled with trefoil flowers in colored marble, was used in the lintel of the sabil window of Frag Ibn Barquq zawia (Figure 7). Another example is seen in the lintel of the sabil window of Qijmas alIshaqi mosque (885-86 A.H./ 1480-81 A.D.). The design takes the shape of a semi-octagonal structure filled with clusters of trefoils and repeated in a rhythmical way with contrasting colours for the trefoils and background.

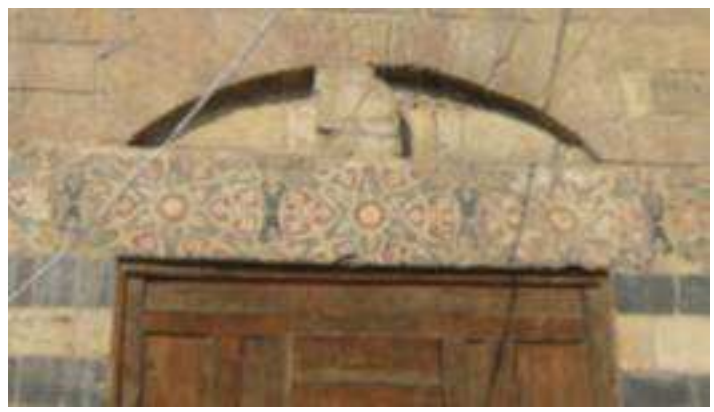

Figure 7: Lintel with geometric decorations of coloured marble- Sabil window of Farag ibn Barquq zawia.

The nafis is the third part of the unit that surmounts doors and windows and it is located between the lintel and the relieving arch. During the Mamluk period the nafis was either left without decoration or decorated with floral decorations carved on stone. The latter was seen in the nafis of the façade windows of Sarghatmish madrasa, alAshraf Barsbay madrasa, Ganim al-Bahlawan madrasa (883-916 A.H./ 1478-1510 A.D.) and Qaytbay sabil. A unique and exceptional example of carved decorations on nafis is seen on the nafis of façade windows of Baybars madrasa (660-62 A.H./1262-63 A.D.); each was decorated with two affronted lions carved on stone, instead of floral decorations. Few examples of Mamluk nafis witnessed the use of coloured tiles for their decoration.

During the Ottoman period some buildings retained the same Mamluk tradition of decorating the nafis with floral decorations such as Sulaymania takiyya, while others preferred coloured tiles instead. The coloured tiles were usually decorated with floral decorations in blue, turquoise and white colours. This could be seen in the nafis of several entrances such as that of Abd al-Rahman Katkhuda zawia (Figure 8), al-Fakahani mosque and Ali alMutahhar mosque. Colored tiles were also used in the nafis of windows of Mustafa Sinan sabil, Hasan Agh Kuklian sabil (1106 A.H./ 1694 A.D.), Abd Allah Katkhuda Azaban sabil, and al-Fakahani sabil. 


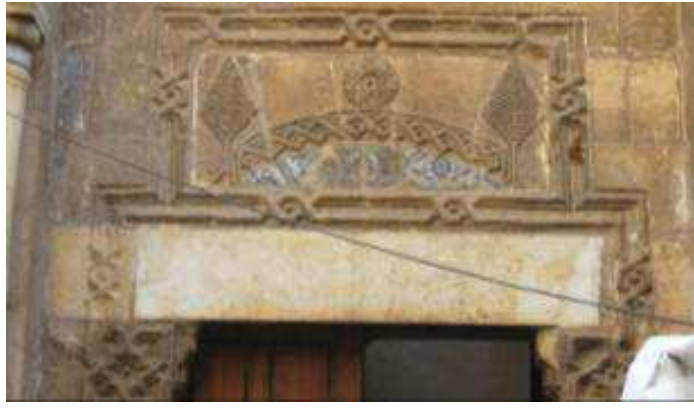

Figure 8: Nafis with coloured tiles- Entrance of Abd alRahman Katkhuda zawia

\section{Part 2: Analysis of the Decorations}

Lintels surmounted with relieving arches were used as an architectural element to support doors and windows in Egypt as early as the Fatimid period; as seen in the entrance and façade windows of alSalih Tala'i mosque (555 A.H./ 1160 A.D.). Joggled voussoirs were used for the construction of lintels as early as the Fatimid period too. They were used in the lintels of Bab al-Nasr, Bab al-Futuh (480 A.H./ 1087 A.D.) and Bab Zuwayla (485 A.H./ 1092 A.D) in addition to the entrance of al-Aqmar mosque (519 A.H./ 1125 A.D.)[18]. Such voussoirs were simple in shape; either stepped, slopping or with concave and convex sides. During the Ayyubid period, simple voussoirs were still in use as seen in the lintels and relieving arches of the entrance and façade windows of al-Salih Najm al-Din Ayyub madrasa (641-48 A.H./ 1243-50 A.D.). Despite the appearance during the Fatimid and Ayyubid period, lintels surmounted with relieving arches were used as a constant architectural element that marked the façades only in the Mamluk period. This unit was widely used above openings of all facades; regardless the function of the building or the status of its patron; that it became a characteristic feature of Mamluk facades. The Ottomans followed the steps of their predecessors and their facades were very similar to the Mamluk ones.

Only at the end of the Ayyubid period, craftsmen added carved decorations on voussoirs of lintels and relieving arches; thus transforming this unit into a decorative unit of the facade. Simple rosettes, trefoil flowers and arabesque decorations were carved on the joggled voussoirs of the lintel of the entrance of al-Salih Najm al-Din Ayyub madrasa in addition to the lintels and relieving arches of the windows of his mausoleum (Figure 9)[18],[19].

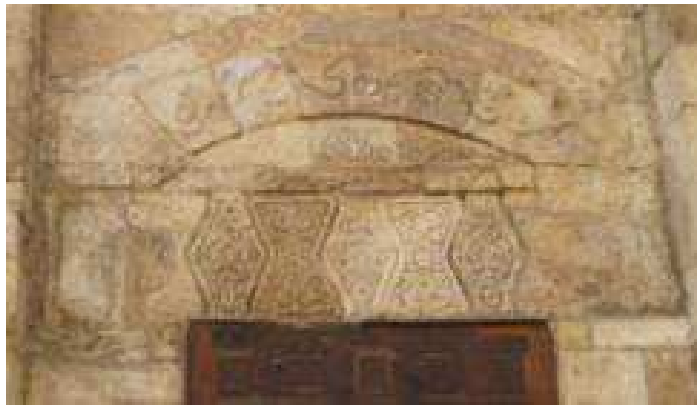

Figure 9: Lintel, nafis and relieving arch with various floral decoration carved on stone- Facade window of al-Salih Najm al-Din Mausoleum.

The same tradition of carving decorations on the simple joggled voussoirs continued during the Mamluk Period and till the Ottoman period. The arabesque for example was used as a decorative element carved on the lintel of entrances of Sarghatmish madrasa, Ganim al-Bahlawan madrasa and the lintel of the side façade window of Sulaymania takiyya (Figure 2). The arabesque decorations were also carved on the relieving arch of the façade windows of al-Nasir Muhammad madrasa, al-Ghawri madrasa and one of the windows of alGhawri sabil. Geometric designs were also carved on simple joggled voussoirs in the form of hexagonal shapes surrounded with interlacing $V$ shapes. This design is witnessed in the lintels of the façade windows of Baybars madrasa and the lintel of the entrance of Sangar al-Gawli madrasa in addition to the lintel of one of its façade windows. The star pattern was also carved on the lintel of one of the façade windows of al-Ghawri sabil and the relieving arches of the façade windows of al-Ghawri madrasa (alternating with arabesque decorations).

An exceptional example of carved decorations is seen on the voussoirs of the relieving arch of the entrance of Abd al-Rahman Katkhuda zawia. The lower edge of the arch was decorated with a plait flanked with two Cypress trees, with zigzag decorations, and surmounted with a circle containing eight-pointed star shape (Figure 8).

In few cases, craftsmen even carved the decoration on the marble slab of the lintel. This is seen in the lintel of the sabil of Abd al-Rahman Katkhuda which was carved with inscriptions (Figure 15). A different exception is seen in the lintel of the entrance of Shaykhu khanqah as the lintel was carved with hieroglyphic inscription[20]; indicating that it was originally an architectural element brought from an ancient Egyptian monument and reused here as a lintel.

The studied examples revealed that the carved decorations were used more frequently during the Bahari Mamluk period, especially when the architect 
used only one colour of stone for the façade. While, joggled voussoirs of coloured marble were used instead during the Circassian Mamluk period. During the Ottoman period, the use of coloured marble was limited and the voussoirs were even plain of carved decorations in most cases.

\section{Types of motifs}

The study of the decorations executed on lintels, nafis and relieving arches reflects a high ability and major skill of craftsmen to use attractive motifs on facades. Generally, floral motifs were the prevailing motifs of lintels, nafis and relieving arches. The trefoil was the dominant motif that was used in diversified forms; alone in a simple form, framed with scrolls in heart shape, unframed with two tires of leaves and complex with stylized leaves (Figure 10).

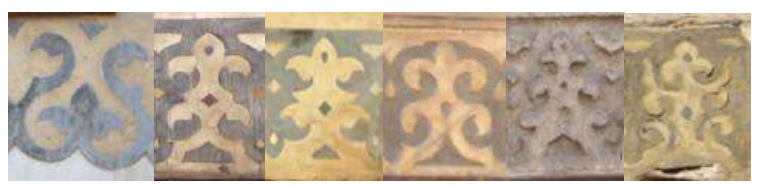

Figure 10: Various types of simple and complex trefoil motif.

Several phases of development reshaped the trefoil and resulted in sophisticated designs. At first, the silhouette of the trefoil stem and base was an ogee, with the upper curve representing the stem and the lower the base. That created the template and its inverse in two steps. Later, the void created by one leaf was at the same time the leaf in reverse, thus reversing the pattern in one step rather than two. The craftsman was skillful enough to treat the trefoil motif differently to create more sophisticated designs. The design on the lintel of the sabil window of Qijmas al-Ishaqi madrasa is a good example of this new treatment. The trefoil was no longer in an upright repetitive position but in clusters. The trefoils appeared to diverge from the center of each cluster, which was semi-octagonal in structure. The final composition was articulated by using a series of black-and-white clusters alternating with one another[21],[22]. The trefoil was also used as filling of a geometric design such as in the lintel of the sabil window of Farag ibn Barquq zawia (Figure 11) and the lintel of the sabil door of Qijmas al-Ishaqi mosque (Figure 12).

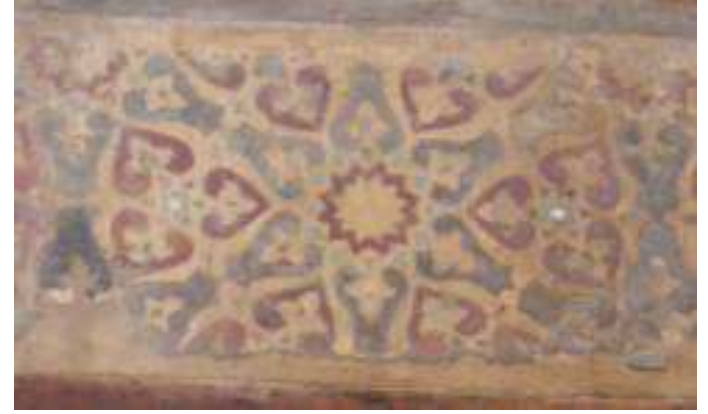

Figure 11: Detail of the star pattern filled with trefoilsLintel of sabil window of Farag ibn Barquq zawia

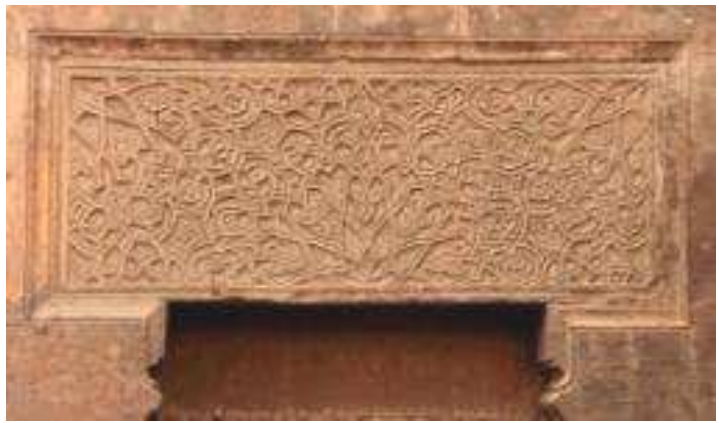

Figure 12: Geometric design filled with trefoil and leavesLintel of sabil door of Qijmas al-Ishaqi madrasa

The arabesque was also preferred by craftsmen, especially for the carved decorations on stone. It represents another sophisticated form of floral decoration. Its limitless, rhythmical alternation of movement, conveyed by the reciprocal repetition of curved lines, produced a design that is balanced and free of tension[23]. The arabesque was intended to reflect the richness of the design and the skill of the craftsman rather than the richness of the material used. This fact is confirmed as the artist chose only the arabesque for the decoration of such a limited area as the nafis (figures 1, 6, 9, 15).

Compared to floral decorations geometric decorations were less frequently used; since they clearly require a high degree of skill of the artist to produce the complexity and sophistication of the required design. The early designs were witnessed on lintels of the façade windows of Baybars madras where designs were based on the hexagonal repeat pattern (Figures 13, 14)[24]. Similar designs were also used during the Bahari Mamluk period such as in the lintel of the entrance and the central façade window of Sangar al-Gawli madrasa. By the Circassian Mamluk period, the star pattern was used whenever geometric decorations were chosen for the decoration of lintels (Figures 7, 11). On the contrary, few evidences were found for the use of geometric decorations on lintels or relieving arches of the Ottoman buildings (Figures 2). 


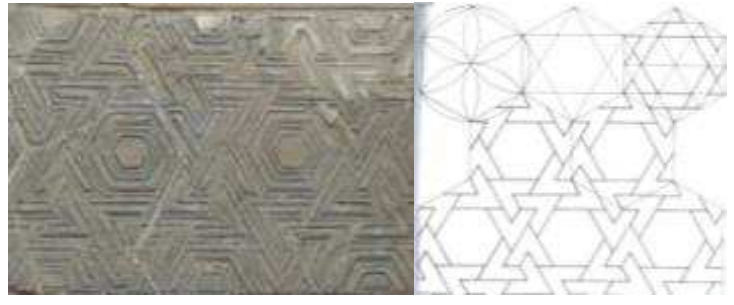

Figure 13: Geometric design of lintel and the way it was drawn based on hexagonal shape- Lintel of one of the the facade windows of Baybars madrasa

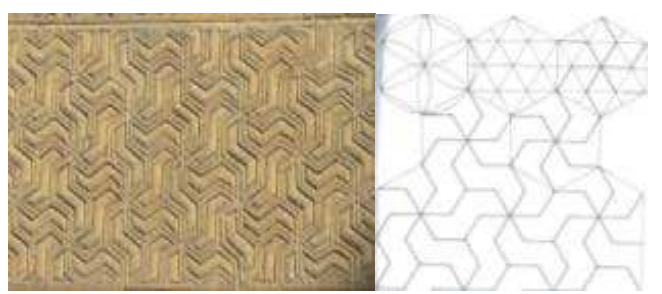

Figure 14: Geometric design of lintel and way it was drawn based on the hexagonal shape- Lintel of one of the facade window of Baybars madrasa

Inscriptions were the least used decorative element on lintels and relieving arches. Only four of the studied monuments revealed using inscriptions on lintels and none on relieving arches. A band of inscription in naskh script was carved on the lintels of the façade windows of Qalawun complex, al-Nasir Muhammad madrasa and Qatlubugha al-Dhahabi madrasa (748 A.H./ 1347 A.D.). The foundation inscription was also carved on the marble lintel of the entrance of Qalawun complex in addition to Abd al-Rahman Katkhuda sabil (Figure 15). The inscription on the latter is a poem written in naskh script in two lines, arranged in six cartouche-like compartments and the marble slab is framed with a frame of floral decorations.

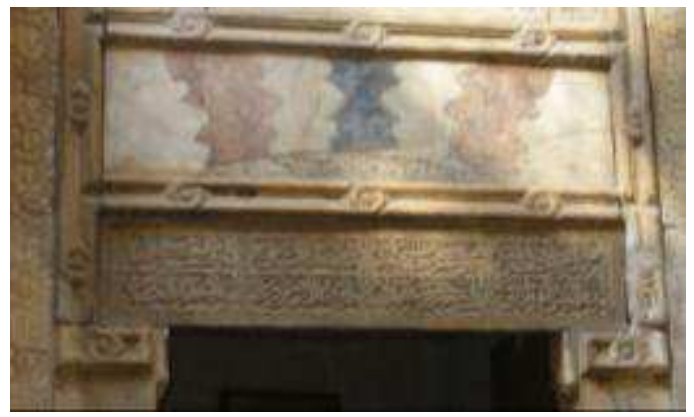

Figure 15: Lintel with carved inscriptions-Entrance of Abd al-Rahman Katkhuda sabil

\section{Tiles on facades}

The Mamluks generally preferred to use marble for the decoration of important spots on facades. Never the less, their fourteenth and fifteenth century buildings witnessed occasional use of tiles as a medium for external and internal architectural decoration[25],[26]. The Mamluk tiles of the fourteenth and beginning of the fifteenth century were decorated with under-glaze painting in blue, white and black and they incorporated Chinese floral ornaments that were influenced with Chinese porcelain and other imported goods that flooded into the Egyptian market due to trade relations[27],[28]. Thus, they displayed more exotic, organically growing vegetal motifs including banana leaves, sprays of fern combining with blooming, winding stalks, swirling leaves and lotus flowers[29]. It is worth mentioning that the fifteenth century also witnessed the activities of Iranian ceramists; especially from Tabriz, who were responsible for the manufacture of large numbers of hexagonal tiles used for architectural decoration[27],[30],[31]. The famous artist and ceramist Ghaybi al-Tawrizi in addition to other artists were responsible for the tileworks in Cairo, Damascus, Edirne and Bursa[30], [32].

Tiles were used for the decoration of the tympanums (nafis) in particular during the fifteenth century as seen in the nafis of the entrance of alKamilia madrasa (622 A.H./ 1166 A.D and 1225 A.H./ 1752 A.D.) (Figure 16) in addition to one in the name of Qaytbay and another in the name of Janbalat[26],[33].

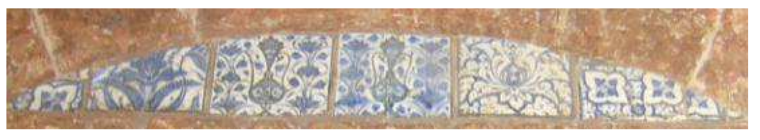

Figure 14: Glazed tiles on the nafis of the entrance- alKamilia madrasa

From the sixteenth century on, the Ottomans used glazed tiles on larger scale for architectural decoration. The famous centers of production were Istanbul; which contained the royal workshops, and Iznik[34]. Iznik tiles were marked with certain features that defined a distinct character of the Ottoman tiles. The standard square and rectangular format of Iznik tiles displaced the fifteenth century tile shapes such as hexagons and triangles arranged to form stars. The colour scheme of these tiles based on blue, turquoise, emerald-green and red executed with a black line over a white ground[35]. The design witnessed the introduction of new vegetal motifs including bunches of grapes with vine leaves, peony scrolls, lotus flowers, pomegranates, pine cones, roses and tulips[36]. That new style of tiles was widely spread all over the Ottoman provinces, either by using original Iznik tiles or their imitations that were locally manufactured[37]. The nafis of entrances and windows on Ottoman Cairene buildings were usually decorated with glazed tiles. Due to their spread, they gave a special identity to the Ottoman facades distinguishing them from other 
facades and articulated the architectural unit above doors and windows.

\section{A focal point of Mamluk and Ottoman facades}

The architectural element above doors and windows of Mamluk and Ottoman facades was treated as a focal point of the façade aiming to attract the attention of the viewer. This was achieved by various means: The first was to verify the building material. The Mamluks generally used stone for building and dressed limestone in particular was the common building material used for facades[38]. Therefore, using marble or granite slabs for lintels in addition to joggled voussoirs of coloured marble for lintels and relieving arches created an eye-catching effect. The use of marble became particularly elaborate in the fifteenth century and formed a major element in Mamluk façade decoration[39]. The architect also took into account that too much marble on the façade would weaken the eye-catching effect intended for the people passing by[40]. Therefore, the use of marble was limited to some of the decorations of the entrance in addition to the decorations of the lintels and relieving arches of the lower level of the façade windows; which were within the line of vision. On the other hand, when the architect used the same material for the lintel and relieving arch as the rest of the façade- that is stone only- he tried to focus on the texture or layout of the stone to create the eyecatching effect. The voussoirs of the lintel and the relieving arch were cut in a size different from the stones of the rest of the façade and arranged in vertical layout as opposed to the horizontal layout of the masonry of the façade. Carved decorations on the voussoirs also created a special texture that accentuated the lintel, nafis and relieving arch and created the required eye-catching effect. The carved part stands out amongst the rest of the glossy smooth façade.

The second way to make the architectural unit above doors and windows a focal point of the façade was to mark it with colours different from the rest of the façade. It is well known that the use of colour was among the characteristic features of the Mamluk style[41]. In fact the Mamluks best invested this feature to highlight the lintels and relieving arches of their façades. During the early Bahari Mamluk period, voussoirs of two different colours were used. This was known as 'ablaq' when black and white colours were used, or 'mushahar' when white and red were used. This method was useful in differentiating the reciprocating or positive and negative shapes by their colour, be in the form of dark and light stone. The use of marble that came into fashion by the second half of the Bahari Mamluk period, and then became prevalent during the Circassian Mamluk period, provided a wider variety of colours including white, black, blue and red. Contrasting colours were preferred to attract the attention of the viewer to the decoration.

Glazed tiles provided another medium to add touches of colour to facades. During the Mamluk period glazed tiles were used on a limited scale for the decoration of the nafis. During the Ottoman period and due to financial reasons, glazed tiles became the most suitable medium to add a touch of colour to the nafis. It was commonly used; especially that marble became limited on voussoirs. Blue and white were the most preferred colors in addition to touches of red and other colors occasionally.

The third way to make the architectural unit above doors and windows a focal point of the façade was the optical effect created by repetition, rhythm and balance. As mentioned before, the Mamluks were following the tradition of their predecessors- The Fatimids and the Ayyubids- in dividing the façade into vertical recesses. The recesses were penetrated with rectangular windows at the lower level and arched windows at the upper level. Thus, the vertical layout of the recesses and the vertical arrangement of the windows were balanced by the horizontal layout of the lintel, nafis and reliving arch of those windows together with the band of inscription that usually runs across that façade[42]. At the same time, the layout of the façades displayed a sort of order and organization in using the decorative element on the façade. Generally, the façade was left undecorated while the unit above doors and windows were richly decorated. This contrast and at the same time balance created a striking optical effect of the decorated areas[43].

Although the architectural unit above doors and windows was repeated along the façade, the architect created balance by varying the decorative elements used among the units. Within each unit, repetition is the main feature that ruled the motifs, yet counterchanges between positive and negative patterns or contrasting colours resulted in creating rhythm with striking optical effect[44],[45]. As mentioned before, the main types of decoration that were generally used for the decoration of lintel, nafis and relieving arch were the floral and geometric designs. They both demonstrate the visual principles of repetition, symmetry and continuous generation of pattern[46],[47]. Yet, craftsmen always managed to use the traditional motif in a new context or add more details to introduce a novel design. That novelty of the design or setting had a powerful eye-catching effect. 


\section{General Remarks}

At this point we might wonder about the factors that determined the choice of the decorations of the lintel, nafis and relieving arch. Was it the choice of the patron, architect or craftsmen? Was there any relation between the function of the building and the type of its decoration? Was there any relation between the location of the building and the choice of the decoration on its façade?

In fact, sources used to describe the buildings with general descriptions reflecting their magnitude and splendor or explaining the socioeconomic aspects of the building. Hardly any description of an urban façade can be found in Mamluk or Ottoman sources[48]. The sources were also silent regarding the views of architects or master builders and their reasons for choosing a certain decoration[49]. All we know is that the architect and the patron were probably responsible for the rough design of the building, while the design of the architectural, structural and decorative details and their actual execution were left to craftsmen[50]. Therefore, it was the skill of craftsmen that determined the choice of the decoration rather than the will of the patron or architect. When decorating a new façade, craftsmen must have been influenced with the decorations of the neighboring buildings and the fashion of the time. In many cases they created a visual continuity or at least a visual communication with the surrounding facades[51]. At the same time, craftsmen were keen to add touches of innovation from time to another to cut the monotony of repletion and show of their skill.
It seems that the function of the building has no influence on the choice of its façade decoration. The studied examples revealed a variety of types of decoration that were used on various types of buildings. On the other hand, the location of the building was more influential, not on the type of the decoration but on its level of richness and sophistication. More attention was paid to the façades of buildings that were overlooking heavily used streets. Since the unit above doors and windows was treated as a focal point to attract the attention of pedestrians, this unit in particular was carefully decorated and new types of decoration and rich material were usually used on facades of buildings overlooking important streets. This is proved when we compare the decoration of this unit on the facades of buildings overlooking al-Mu'iz Street, for example, to other streets of less importance.

\section{Conclusion}

One of the main features that marked the façades of the Mamluk and Ottoman buildings in Cairo was the architectural unit above doors and windows which included the lintel, nafis and relieving arch. The construction and decoration of that unit went through various stages of development and revealed a wide variety of decorative patterns. That variety reflects a rich and sumptuous effect in some cases and a modest yet skillful effect in other cases. This unit was treated as a focal point of the façade with eye-catching power that is created from the design, material, texture, repetition and balance of its decoration.

Table 1. The four studied streets with their monuments Al-Mu'iz Street: from Bab Zuwayla in the south to Bab al-Nasr in the north.

\begin{tabular}{|c|c|c|c|c|}
\hline $\begin{array}{l}\text { Monument } \\
\text { name }\end{array}$ & $\begin{array}{l}\text { Monument } \\
\text { number }\end{array}$ & Date of building & Era & $\begin{array}{l}\text { Location on left/ } \\
\text { right of St. }\end{array}$ \\
\hline Bab Zuwayla & 199 & 485 A.H./ 1092 A.D. & Fatimid & Centre \\
\hline Al-Mu'ayyad mosque & 190 & 818-23 A.H./ 1415-20 A.D. & Circassian Mamluk & Left \\
\hline Al-Fakahani mosque & 109 & 1148 A.H./ 1735 A.D. & Ottoman & Right \\
\hline \multirow[t]{3}{*}{ Al-Ghawri khanqah, sabil, kuttab and masouleum } & 65 & 909-10 A.H./ 1504-5 A.D. & Circassian Mamluk & Right \\
\hline & 65 & & & \\
\hline & 67 & & & \\
\hline Al-Ghawri madrasa & 189 & 909-10 A.H./ 1504-5 A.D. & Circassian Mamluk & Left \\
\hline Al-Ashraf Barsbay madrasa & 175 & 829 A.H./ 1425 A.D. & Circassian Mamluk & Left \\
\hline Ali al-Mutahhar mosque & 40 & 1157 A.H./ 1744 A.D. & Ottoman & Left \\
\hline Al-Salih Najm al-Din Ayyub madrasa & 38 & 641-48 A.H./ 1243-50 A.D. & Ayyubid & Right \\
\hline Baybars madrasa & 37 & 660-62 A.H./ 1262-63 A.D. & Bahari Mamluk & Right \\
\hline Qalawun complex & 43 & 683-84 A.H./ 1284-85 A.D. & Bahari Mamluk & Left \\
\hline Khusraw sabil and kuttab & 52 & 942 A.H./ 1535 A.D. & Ottoman & Right \\
\hline Al-Nasir Muhammad madrasa & 44 & 695-703 A.H./ 1295-1304 A.D. & Bahari Mamluk & Left \\
\hline Barquq madrasa & 187 & 786-88 A.H./ 1384-86 A.D. & Circassian Mamluk & Left \\
\hline \multirow[t]{2}{*}{ Al-Kamilia madrasa } & 428 & 622 A.H./ 1225 A.D. & Ayyubid/ & Left \\
\hline & & 1166 A.H./ 1752 A.D. & Ottoman & \\
\hline Abd al-Rahman Katkhuda sabil and kuttab & 21 & 1157 A.H./ 1744 A.D. & Ottoman & Centre \\
\hline Aqmar mosque & 33 & 519 A.H./ 1125 A.D. & Fatimid & Right \\
\hline Bab al-Nasr & 7 & 480 A.H./ 1087 A.D. & Fatimid & Centre \\
\hline
\end{tabular}


Table 2. Al-Surugia, al-Megharbelin and al-Khayamia: from Muhammad Ali Street in the south to Bab Zuwayla in the north.

\begin{tabular}{|c|c|c|c|c|}
\hline $\begin{array}{l}\text { Monument } \\
\text { name }\end{array}$ & $\begin{array}{l}\text { Monument } \\
\text { number }\end{array}$ & Date of building & Era & $\begin{array}{l}\text { Location on left/ } \\
\text { right of St. }\end{array}$ \\
\hline Sulaymania takkiya & 225 & 950 A.H./ 1543 A.D & Ottoman & Right \\
\hline Ganim al-Bahlawan madrasa & 129 & $\begin{array}{l}\text { 883- } 916 \text { A.H/ 1478- } 1510 \\
\text { A.D. }\end{array}$ & Circassian Mamluk & Right \\
\hline Jani Bek mosque & 119 & 830 A.H./ 1426-27 A.D. & Circassian Mamluk & Right \\
\hline Abd al-Rahman Katkhuda zawia & 214 & 1142 A.H./ 1729 A.D. & Ottoman & Right \\
\hline Inal al-Yusufi madrasa & 118 & 794-95 A.H./ 1392-93 A.D. & Circassian Mamluk & Right \\
\hline Al-Kurdi mosque & 117 & $\begin{array}{l}797 \text { A.H./ } 1395 \text { A.D } \\
1145 \text { A.H./ } 1732 \text { A.D. }\end{array}$ & $\begin{array}{l}\text { Circassian Mamluk/ } \\
\text { Ottoman }\end{array}$ & Right \\
\hline Al-Salih Tala'i mosque & 116 & 555 A.H./ 1160 A.D. & Fatimid & Right \\
\hline Farag ibn Barquq zawia & 203 & 811 A.H./ 1408 A.D. & Circassian Mamluk & Left \\
\hline
\end{tabular}

Table 3. Suq al-Silah Street: from near al-Rifa'i mosque, running north and turning left till it intersects with alKhayamia Street, south of Bab Zuwayla.

\begin{tabular}{lllll}
\hline Monument name & $\begin{array}{l}\text { Monument } \\
\text { number }\end{array}$ & Date of building & Era & $\begin{array}{l}\text { Location on } \\
\text { right of St. }\end{array}$ \\
\hline Ulgay al-Yusufi madrasa & 131 & 774 A.H./ 1373 A.D. & Bahari Mamluk & Right \\
Mustafa Sinan sabil & 246 & 1040 A.H./ 1630 A.D. & Ottoman & Left \\
Sudun min Zada madrasa & 127 & 804 A.H./ 1401 A.D. & Circassian Mamluk & Right \\
Hasan Agha Kuklian sabil and kuttab & 243 & 1106 A.H./ 1694 A.D. & Ottoman & Right \\
Qatlubugha al-Dhahabi madrasa & 242 & 748 A.H./ 1347 A.D. & Bahari Mamluk & Left \\
Al-Maridani mosque & 130 & $739-40$ A.H./ 1339-40 A.D. & Bahari Mamluk & Left \\
Ahmad al-Mihmandar mosque & 115 & 725 A.H./ 1324-25 A.D. & Bahari Mamluk & Left \\
Qijmas al-Ishaqi mosque & 114 & $885-86$ A.H./ 1480-81 A.D. & Circassian Mamluk & Right \\
\hline
\end{tabular}

Table 4. Al-Saliba Street: from Salah al-Din square in the east to al-Sayeda Zainab square in the west.

\begin{tabular}{lllll}
\hline $\begin{array}{l}\text { Monument } \\
\text { name }\end{array}$ & $\begin{array}{l}\text { Monument } \\
\text { number }\end{array}$ & Date of building & Era & $\begin{array}{l}\text { Location on } \\
\text { right of St. }\end{array}$ \\
\hline Qaytbay sabil and kuttab & 324 & 884 A.H./ 1479 A.D. & Circassian Mamluk & Left \\
Qanibay mosque & 151 & 816 A.H./ 1413 A.D. & Circassian Mamluk & Left \\
Abd Allah Katkhuda sabil & 452 & 1132 A.H./ 1719 A.D. & Ottoman & Left \\
Shaykhu mosque & 147 & 750 A.H./ 1349 A.D. & Bahari Mamluk & Right \\
Shaykhu khanqah & 152 & 756 A.H./ 1355 & Bahari Mamluk & Left \\
Taghri Bardi madrasa & 209 & 844 A.H./ 1440 A.D. & Circassian Mamluk & Right \\
Sarghatmish madrasa & 258 & 757 A.H./ 1356 A.D. & Bahari Mamluk & Left \\
Sangar al-Gawli madrasa & 221 & 703 A.H/ 1303-4 A.D. & Bahari Mamluk & Left \\
Yusuf Bek sabil & 219 & 1044 A.H./ 1634 A.D. & Ottoman & Left \\
Lajin al-Sayfi mosque & 217 & 853 A.H./ 1449 A.D. & Circassian Mamluk & Right \\
\hline
\end{tabular}

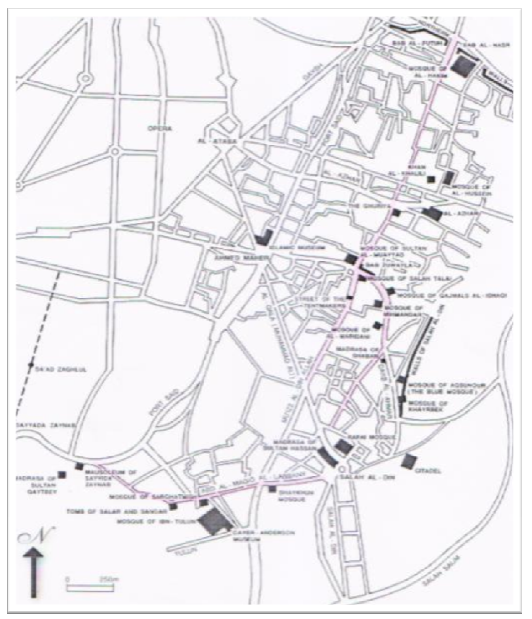

Map 1: Map of al-Qahira showing the four studied streets

\section{References}

[1] Doris Behrens-Abouseif, Cairo of the Mamluks. 2007, p. 104.

[2] Muhammad H. Al-Hadad, al-Madkhal ela Derasat al-Mustalahat al-Fanniyya li-lcmara al-Islamiyya. Cairo, 2008, p. 94.

[3] Muhammad M. Amin and Laila A. Ibrahim, alMustalahat al-Micmariyya fi al-Wathaiq alMamlukiyya. Cairo, 1990, p. 80.

[4] A. Petersen, Dictionary of Islamic Architecture. London, 1996, p. 24.

[5] A. Petersen, "The Grove Encyclopedia of Islamic Art and Architecture," Oxford, vol. vol.2. p. 66, 2009.

[6] Britannica Concise Encyclopedia. USA, 2003, p. 94.

[7] Sami M. Nawar, al-Kamel fi Mustalahat alcmara Al-Islamiyya min Butun al-Macagem 
al-Lughawiyya. Alexandria, 2003, pp. 126127.

[8] Muhammad H. Al-Hadad, al-Madkhal ela Derasat al-Mustalahat al-Fanniyya li-lcmara al-Islamiyya. 2008, p. 100.

[9] Gamal Abdel Rehim Ibrahim, al-Helyat alMecmariyya al-Zukhrufiyya cla cma'er alQahira fi al-csr al-Mamluki al-Garkasi. Ph.D. diss., Cairo University, 1991, pp. 22-36.

[10] Manar A. Hafiz, Zakharef Wagehat alAsbelah fi al-Qahira al-Mamlukiyya. MA. Thesis, Alexandria University, 2009, pp. 138149.

[11] Ibrahim, al-Helyat. p. 22

[12] wilfred G Dilly, al-cemara al-crabiyya bi Masr, trans. Mahmud Ahmad. Cairo, 2000, p. 34.

[13] Khaled Asfour, Learning from Mamluk Architecture, in The cairo Heritage, ed. Doris Behrens-Abouseif. Cairo-NY, 2000, p. 253.

[14] E. Kuhnel, Arabesque, Encyclopaedia of Islam I. 1986, pp. 558-561.

[15] O. Graber, The Formation of Islamic Art. Yale University, 1987, pp. 187-190.

[16] Wijdan Ali, What is Islamic Art? Jordan, 1998, pp. 41-43.

[17] Eva Baer, Islamic Ornament. Edinburgh, 1998, pp. 15-23.

[18] Ibrahim, al-Helyat. p. 26.

[19] A. al-N. Yasin, al-Funun al-Zukhrufiyya alIslamiyya bi Masr fi al-csr al-Ayyubi. Alexandria, 2002, p. 382.

[20] Doris Behrens-Abouseif, Cairo of the Mamluks: A History of the Architecture and Its Cultures. Cairo, 2007, p. 195.

[21] Khaled Asfour, Learning from Mamluk Architecture in the Cairo Heritage, ed Doris Behrens-Abouseif. Cairo-NY, 2000, pp. 255256.

[22] Manar A. Hafiz, Zakharef Wagehat alAsbelah fi al-Qahira al-Mamlukiyya. MA. Thesis, Alexandria University, 2009, p. 145.

[23] Dalu Jones, Surface, Pattern and Light', in Architecture of the Islamic World: Its History and Social Meaning, ed. George Michell. London, 2000, p. 171.

[24] Issam El-Said and Ayse Perman, Geometric Concept in Islamic Art. pp. 51-63.

[25] Marilyn Jenkins, Mamluk Underglaze-Painted Pottery: Foundation for Future Study', Muqarnas 2. 1984, p. 104; Pl.2-a; pl. 6-c.

[26] Doris Behrens-Abouseif, Cairo of the Mamluks. 2007, p. 90.

[27] Marilyn Jenkins, “Islamic Pottery: A Brief History, The Metropolitan Museum of Art Bulletin," vol. 40/4, p. 36, 1983.

[28] O. Watson, Ceramics from Islamic Lands. London, 2004, p. 417.

[29] Eva Baer, Islamic Ornament. Edinburgh, 1998, p. 24.

[30] Marilyn Jenkins, Mamluk Underglaze-Painted Pottery: Foundation for Future Study', Muqarnas 2. 1984, pp. 104-112.
[31] Geza Fehervari, Ceramics of the Islamic World in the Tareq Rajab Museum. LondonNew York, 2000, pp. 249- 251.

[32] Gulru Necipoglu, From International Timurid to Ottoman: A Change of Taste in SixteenthCentury Ceramic Tiles, Muqarnas 7. 1990, p. 137.

[33] Marilyn Jenkins, Mamluk Underglaze-Painted Pottery, Foundation for Future Study, Muqarnas 2. 1984, p. pl 9 a,pl 311.

[34] Gulru Necipoglu, From International Timurid to Ottoman: A Change of Taste in SixteenthCentury Ceramic Tiles,Muqarnas 7. 1990, pp. 137-141.

[35] Gulru Necipoglu, From International Timurid to Ottoman: A Change of Taste in SixteenthCentury Ceramic Tiles, Muqarnas 7. 1990, p. 157.

[36] Eva Baer, Islamic Ornament. Edinburgh, 1998, pp. 25-27.

[37] Walter Denny, “Blue-and-White Islamic Pottery on Chinese Themes, Boston Museum Bulletin," vol. vol. 72/ 3, p. 92, 1974.

[38] Docaa Abd al-Salam, Derasa Tahliliyya li estekhdamat al-Ahgar al-Tabicia fi al-cmara al-Mamlukiyya bi al-Qahira. MA Thesis, Helwan University, 2009, pp. 163-166.

[39] Doris Behrens-Abouseif, Cairo of the Mamluks. 2007, p. 91.

[40] K. Asfour, Learning from Mamluk Architecture, in The Cairo Heritage, ed. Doris Behrens-Abouseif. Cairo-NY, 2000, p. 253.

[41] Stephen Humphreys, "The Expressive Intent of the Mamluk Architecture of Cairo: A Preliminary Essay," Stud. Islam. 33, p. 98, 1972.

[42] Howayda Al-Harithy, The Concept of Space in Mamluk Architecture, Muqarnas 18. 2001, p. 80,88.

[43] E. John Vreize, Heavenly Art- Earthly Art: The Art of Islam. Amsterdam, 2000, p. 55.

[44] M. A. al-R. Muhammad, Zaherat al-Tekrar fi al-Funun al-Islamiyya. Cairo, 1997, pp. 2547.

[45] Mai A. Hawas, Tathir al-Madhahib cal alcmara al-Diniyya al-Islamiyya lil-masajed. MA Thesis, Helwan University, 2006, pp. 107111.

[46] Jones, Surface, Pattern and Light. p. 169.

[47] Sema Etikan, "The Principles of Ornament in Islamic Art and Effects of these Principles on the Turkish Carpet Art, Current Research Journal of Social Science 3,” p. 89, 2011.

[48] Nasser Rabbat, Perception of Architecture in Mamluk Sources, in Mamluk History through Architecture. Egypt, 2010, p. 25.

[49] Nasser Rabbat, Perception of Architecture in Mamluk Sources, in mamluk History through Architecture. Egypt, 2010, p. 32.

[50] Nasser Rabbat, Architects and Artists in Mamluk Society: The Perspective of the 
Sources' in Mamluk History through Architecture. Egypt, 2010, p. 34.
[51] H. Al-Harithy, "The Concept of Space in Mamluk Architecture', Muqarnas 18," pp. 80, 88, 2001. 